\title{
Large scale study of the within and between spatial variability of lead, arsenic, and cadmium contamination of cow milk in China
}

\author{
Xuewei Zhou ${ }^{\text {a,b,c }}$, Xueyin Qu ${ }^{\text {a,b }}$, Nan Zheng ${ }^{a, b, *}$, Chuanyou Su ${ }^{\text {a,b }}$, Jiaqi Wang ${ }^{\text {a,b }}$, Helene Soyeurt ${ }^{c}$ \\ ${ }^{a}$ Ministry of Agriculture-Key Laboratory of Quality \& Safety Control for Milk and Dairy Products, Institute of Animal Sciences, Chinese Academy of Agricultural Sciences, Beijing 100193, PR China \\ ${ }^{\mathrm{b}}$ Ministry of Agriculture-Laboratory of Quality and Safety Risk Assessment for Dairy Products, Beijing, PR China \\ c AGROBIOCHEM department and Teaching and Research Centre (TERRA), Gembloux Agro-Bio Tech, University of Liège, 5030 Gembloux, Belgium
}

\section{H I G H L I G H T S}

- Lead, As and Cd in raw milk from 10 main milk producing areas in China were measured.

- Levels of Pb, As, and Cd showed significant differences between studied areas.

- Spatial distribution of milk $\mathrm{Pb}$, As, and Cd was depicted by ordinary kriging method.

\section{G R A P H I C A L A B S T R A C T}

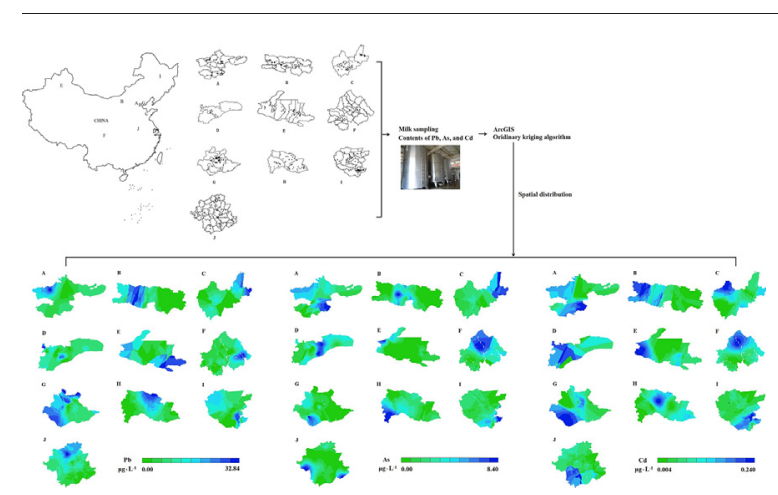

\begin{abstract}
A B S T R A C T
This large scale study investigated the spatial variability of $\mathrm{Pb}$, As, and $\mathrm{Cd}$ contents in raw milk within and between the 10 main milk producing areas in China. A total of 997 raw milk samples were analysed by inductively coupled plasma mass spectrometry (ICP-MS). Mean values of Pb, As, and Cd in milk were $1.75 \mu \mathrm{g} / \mathrm{L}, 0.31 \mu \mathrm{g} / \mathrm{L}$, and $0.05 \mu \mathrm{g} / \mathrm{L}$, respectively. The highest level of $\mathrm{Pb}$ and As was present in area C, and Cd was highest in area J. The standard deviation suggested a higher heterogeneity of milk heavy metal contamination within area than between areas. Levels of $\mathrm{Pb}$, As, and $\mathrm{Cd}$ showed significant differences between studied areas. The estimated root mean squared standardised error obtained by the cross-validation suggested a differentiated quality of $\mathrm{Pb}, \mathrm{As}$, and $\mathrm{Cd}$ modelling between areas: the predictions obtained were sometimes overestimated or underestimated. These results can be used to define a more appropriate sampling procedure for heavy metal contaminate distribution in raw milk for improved future control of milk contamination by heavy metals in the studied areas. The significant positive correlations between concentrations of $\mathrm{Pb}-\mathrm{Cd}$, As- $\mathrm{Cd}$, and $\mathrm{Pb}-\mathrm{As}$ were observed in nine, six and five areas, respectively. No significant negative correlations were observed. The observed variability of correlation values suggested a different pollution source for $\mathrm{Pb}, \mathrm{As}$, and $\mathrm{Cd}$ in milk between areas. Further studies are required to clarify the relationships between the contamination of raw milk by heavy metals and the herd environment.
\end{abstract}

(C) 2018 Published by Elsevier B.V.

\footnotetext{
* Corresponding author at: Institute of Animal Sciences, Chinese Academy of Agricultral Sciences, No.2 Yuanmingyuan West Road, Haidian District, Beijing 100193, PR China.

E-mail address: zhengnan@caas.cn (N. Zheng).
}

\section{Introduction}

Milk and dairy products contain protein, fat, and other elements essential for human health, especially for body metabolism, growth, and 
development. Minerals are considered essential elements. For instance, calcium, copper, and selenium are essential minerals for normal human body functions, as they are involved in many physiological processes (Alasalvara et al., 2002; Licata et al., 2012). However, heavy metals such as lead $(\mathrm{Pb})$, arsenic (As), and cadmium (Cd) may also be found in milk (Swarup et al., 2005; Shailaja et al., 2014). If they are consumed in excessive concentrations, these heavy metals can lead to serious systemic health problems (Oliver, 1997). This can occur when the foodstuff is contaminated by heavy metals present in the production environment. For instance, Swarup et al. (2005) showed that blood Pb levels in lactating cows reared around lead zinc smelting factories were significantly higher than those in non-polluted areas. Shailaja et al. (2014) suggested that contaminated fodder given to buffalos might be one factor responsible for elevated $\mathrm{Pb}$ levels in blood and milk. The same observations can be made for other heavy metals such as As. For instance, contaminated drinking water and food are the most important routes of As exposure (Ohno et al., 2007; WHO, 2010). Therefore, there is a link between the environment/localisation of the dairy farms and the number of contaminated ruminants.

Few investigations have been conducted to study this relationship in raw cow milk. Qu et al. (2013) measured Pb, As, and Cd in 192 raw milk samples from 7 districts of Tangshan city, to find an average of 35.13 $\mu \mathrm{g} / \mathrm{kg}, 95.85 \mu \mathrm{g} / \mathrm{kg}$, and $41.35 \mu \mathrm{g} / \mathrm{kg}$, respectively. The levels of these metals were relatively higher in the industrial district. These findings confirmed the results obtained previously by Malhat et al. (2012) from 100 milk samples, and by Temiz and Soylu (2012) from 144 raw milk samples. Rahimi (2013) extended this study to 137 goat, cow, sheep, and buffalo milk samples. Those authors confirmed that an environmental relationship was responsible for milk contamination. More recently, from a limited number of samples $(n=40)$, Zhou et al. (2016) showed differences in heavy metal concentrations in raw milk collected in two different Chinese provinces (Shandong and Shaanxi province). In conclusion, all of these studies suggest the existence of spatial variability in milk heavy metal contamination related to the production environment.
Unfortunately, there is a lack of large scale studies to allow detailed investigation of the spatial distribution of these heavy metal contaminants in raw cow milk. Therefore, the present research aims to study the variability of $\mathrm{Pb}, \mathrm{As}$, and $\mathrm{Cd}$ within and between the main milk producing areas in China, thanks to a large scale design. This study will contribute to improve knowledge of the existing variability of this type of milk contamination in China. This can be used to refine the definition of an appropriate sampling procedure for regular control of the evolution of heavy metal contamination in milk.

\section{Materials and methods}

\subsection{Sample collection}

The study was conducted in the ten main Chinese milk producing areas marked in Fig. 1 with A (part of Beijing: $39^{\circ} 54^{\prime}-40^{\circ} 58^{\prime} \mathrm{N}$, $115^{\circ} 39^{\prime}-117^{\circ} 52^{\prime} \mathrm{E}$ ), B (part of Inner Mongolia: $40^{\circ} 53^{\prime}-41^{\circ} 11^{\prime} \mathrm{N}$, $109^{\circ} 71^{\prime}-112^{\circ} 30^{\prime} \mathrm{E}$ ), C (part of Shandong: $36^{\circ} 30^{\prime}-36^{\circ} 95^{\prime} \mathrm{N}, 118^{\circ} 38^{\prime}$ $119^{\circ} 32^{\prime} \mathrm{E}$ ), D (part of Shanghai: $30^{\circ} 72^{\prime}-31^{\circ} 02^{\prime} \mathrm{N}, 121^{\circ} 00^{\prime}-121^{\circ} 55^{\prime}$ E), E (part of Xinjiang: $43^{\circ} 54^{\prime}-45^{\circ} 45^{\prime} \mathrm{N}, 84^{\circ} 11^{\prime}-87^{\circ} 67^{\prime} \mathrm{E}$ ), F (part of Sichuan: $30^{\circ} 31^{\prime}-31^{\circ} 18^{\prime} \mathrm{N}, 103^{\circ} 41^{\prime}-104^{\circ} 81^{\prime} \mathrm{E}$ ), G (part of Hebei: $39^{\circ} 01^{\prime}-39^{\circ} 92^{\prime} \mathrm{N}, 118^{\circ} 81^{\prime}-118^{\circ} 97^{\prime} \mathrm{E}$ ), $\mathrm{H}$ (part of Tianjin: $39^{\circ} 01^{\prime}$ $39^{\circ} 86^{\prime} \mathrm{N}, 116^{\circ} 96^{\prime}-118^{\circ} 97^{\prime} \mathrm{E}$ ), I (part of Heilongjiang: $45^{\circ} 00^{\prime}-47^{\circ} 23^{\prime}$ $\mathrm{N}, 124^{\circ} 13^{\prime}-126^{\circ} 68^{\prime} \mathrm{E}$ ), and J (part of Anhui: $31^{\circ} 64^{\prime}-34^{\circ} 29^{\prime} \mathrm{N}$, $\left.115^{\circ} 09^{\prime}-118^{\circ} 75^{\prime} \mathrm{E}\right)$. The farms were selected randomly for sampling. A total of 997 milk samples were collected on 568 farms. This represented 100 milk samples per area studied, except for area $\mathrm{H}(n=97)$. The sampling was realised between May and August 2016. All samples were collected in $200 \mathrm{~mL}$ polypropylene bottles and stored at $-20^{\circ} \mathrm{C}$ in the laboratory.

\subsection{Heavy metal measurement}

All reagents were analytically pure. Water used in the analytical process was obtained from a Milli-Q Plus water purification system

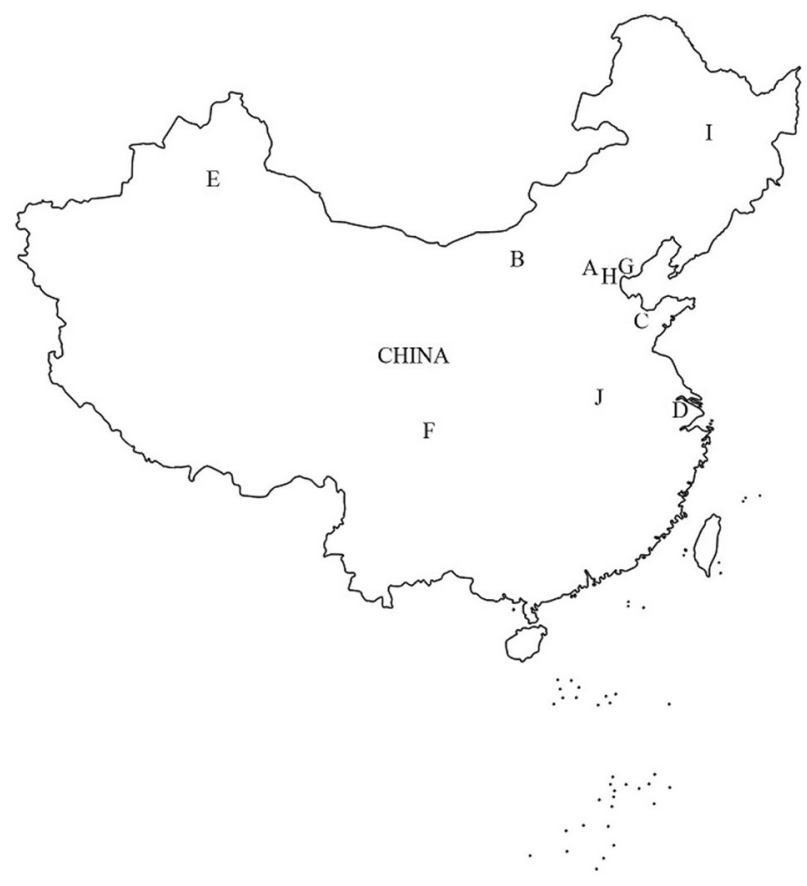

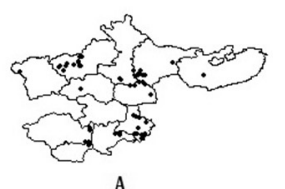

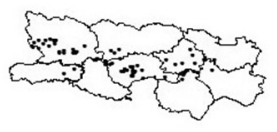

B

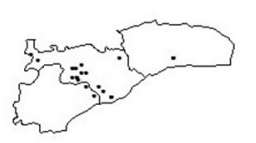

D

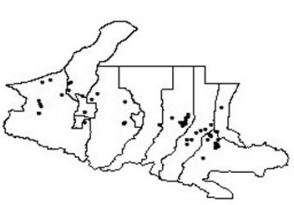

E
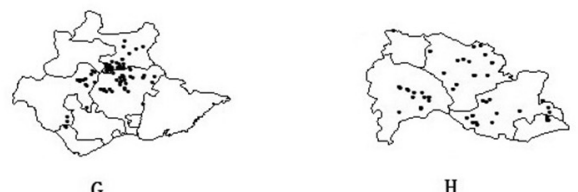

$\mathrm{H}$

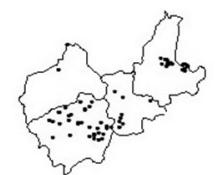

C
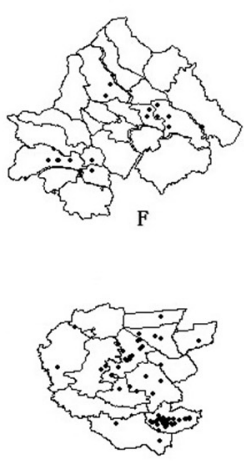

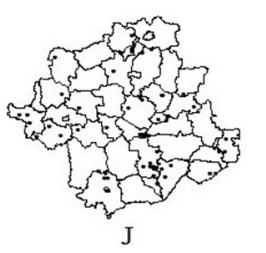

Fig. 1. Map of the sampling area. Dots on the map are the locations of sampling. 
(18.2 $\mathrm{M} \Omega \mathrm{cm}$ ) (Millipore, USA). Nitric acid (65\%) and hydrogen peroxide (30\%) used in sample digestion were obtained from Merck (Germany). All the vessels were immersed in $20 \% \mathrm{HNO}_{3}(\mathrm{v} / \mathrm{v})$ for at least $12 \mathrm{~h}$ and rinsed with ultrapure water before analysis.

Raw milk samples of $1 \mathrm{~mL}$ were digested with microwaves after adding $4 \mathrm{~mL} \mathrm{HNO}_{3}$ and $3 \mathrm{~mL} \mathrm{H} \mathrm{H}_{2}$ in polytetrafluoroethylene (PTFE) tubes. A MARS 6 microwave sample digestion system (MARS6, CEM Corporation, USA) with a power of $1600 \mathrm{~W}$ was used for the digestion of milk samples. This digestion was performed according to the method by Zhou et al. (2016): (1) ramp time $5 \mathrm{~min}$, temperature $90^{\circ} \mathrm{C}$, hold time $5 \mathrm{~min}$; (2) ramp time $5 \mathrm{~min}$, temperature $150{ }^{\circ} \mathrm{C}$, hold time $10 \mathrm{~min}$; and (3) ramp time $5 \mathrm{~min}$, temperature $180{ }^{\circ} \mathrm{C}$, hold time $20 \mathrm{~min}$. Digested samples were allowed to cool to room temperature, transferred to polypropylene tubes (Corning, USA), and diluted to $50 \mathrm{~mL}$ with ultrapure water. Blanks, devoid of samples, were subject to the same digestion procedures during sample preparation. The contents of $\mathrm{Pb}$, As, and Cd were measured by ICP-MS (7700x, Agilent, USA) with helium gas reaction model.

Standard calibrations were developed to quantify the contents of $\mathrm{Pb}$, As, and Cd in raw milk samples. For this, standard solutions were prepared from multi-element stock standard solution $(10 \mathrm{mg} / \mathrm{L}$, SPEX, USA). The linear regression coefficients $(R)$ of the calibration curves were considered acceptable when $R>0.9995$. During the whole measurement, the calibration curves for $\mathrm{Pb}, \mathrm{As}$, and $\mathrm{Cd}$ were prepared with five points (1, 2, 3, 4, $5 \mu \mathrm{g} / \mathrm{L}$, blank not included). Limit of detection (LOD) was calculated from 3 times the standard deviation of the sample blank, relative to the slope of the analytical curve. The digested milks were used in the calculation of LOD. The LOD for $\mathrm{Pb}, \mathrm{As}$, and $\mathrm{Cd}$ were $0.28 \mu \mathrm{g} / \mathrm{L}, 0.09 \mu \mathrm{g} / \mathrm{L}$, and $2.89 \times 10^{-3} \mu \mathrm{g} / \mathrm{L}$, respectively.

Samples spiked with standard solution were used to verify the accuracy of the method. The recovery rates of $\mathrm{Pb}, \mathrm{As}$, and $\mathrm{Cd}$ in milk were $97.1 \%, 94.4 \%$, and $95.5 \%$. Concentrations below LOD were replaced by half the value of the respective detection limits, as proposed by Potorti et al. (2013) (i.e., $0.14,0.045$, and $1.445 \times 10^{-3} \mu \mathrm{g} / \mathrm{L}$ for $\mathrm{Pb}, \mathrm{As}$, and $\mathrm{Cd}$ ).

\subsection{Statistical analysis}

All statistical analyses were performed using SAS 9.4 software (Cary, NC, USA).

The variability of milk heavy metal contamination within milk producing areas was assessed by calculating the standard deviation of measured $\mathrm{Pb}, \mathrm{As}$, and $\mathrm{Cd}$ levels, as well as by estimating the positive rate defined by the number of contaminated samples per area. The spatial distribution patterns of $\mathrm{Pb}, \mathrm{As}$, and $\mathrm{Cd}$ within studied areas were modelled by ArcGIS 10.2 mapping software (ESRI, New York, USA) using the ordinary kriging algorithm. A leave-one-out cross-validation was performed to assess the prediction performances of the obtained distribution map. To evaluate the unbiased characteristic of the predictions and their uncertainty, some statistical parameters were calculated. The uncertainty was assessed by estimating the root mean squared error (RMSE). As the $\mathrm{Pb}, \mathrm{As}$, and Cd levels presented at different scales and in order to compare the different developed kriging models, the root mean squared error was standardised. This parameter was calculated using the prediction errors divided by its corresponding prediction standard error (RMSSE). RMSSE was used to assess the uncertainly of the predictions. A RMSSE value higher than 1 means an underestimation of the variability of the studied traits in the predictions. Conversely, RMSSE lower than 1 means an overestimation. Therefore, the difference in RMSSE-1 was calculated to compare the uncertainty between the developed kriging models. The predictions were estimated to be unbiased when their mean of standardised prediction error (MSE) was close to zero.

To assess the variability of milk heavy metal contamination between studied areas, non-parametric Kruskal-Wallis tests were performed, because the data were not normally distributed based on the results of the Shapiro-Wilk test. Area was considered as a fixed effect in the model.
Pairwise two-sided multiple comparisons were performed using the Dwass, Steek, Critchlow-Fligner method. Differences were assumed significant when the $P$-value was lower than $5 \%$. Finally, Spearman correlations were calculated to assess the relationships between observed $\mathrm{Pb}$, As, and Cd contents within each studied area. A P-value lower than 5\% means a correlation siginificantly different than 0 .

\section{Results}

\subsection{Concentrations of $\mathrm{Pb}, \mathrm{As}$, and $\mathrm{Cd}$ in raw milk samples}

The average level of $\mathrm{Pb}, \mathrm{As}$, and $\mathrm{Cd}$ in studied milk samples were equal to $1.75,0.31$, and $0.05 \mu \mathrm{g} / \mathrm{L}$, respectively. Average levels of $\mathrm{Pb}$ in milk produced in the ten studied areas showed the descending average content as follows: $\mathrm{E}>\mathrm{D}>\mathrm{A}>\mathrm{G}>\mathrm{J}>\mathrm{C}>\mathrm{B}>\mathrm{F}>\mathrm{H}>\mathrm{I}$ (Table 1). Average levels of As and Cd ranged from $0.13-0.80 \mu \mathrm{g} / \mathrm{L}$ and $0.02-0.09 \mu \mathrm{g} / \mathrm{L}$, respectively, and the highest average contents were found in areas J and A. The maximum levels of $\mathrm{Pb}$ and As were detected in the same sample from area $\mathrm{C}$, while $\mathrm{Cd}$ was highest in area $\mathrm{J}$ (Table 1 ).

The observed values of $\mathrm{Pb}$ in all samples were below the Chinese maximum residue limit (MRL) (i.e., $0.05 \mathrm{mg} / \mathrm{kg}$ for $\mathrm{Pb}$ ) (CFDA\&NHC, 2017). However, $1.20 \%$ of samples (i.e., 12 samples out of 997) were above the MRL recommended by the European Union $(0.02 \mathrm{mg} / \mathrm{kg})$ (EC., 2015), and these samples were from 4 regions. The MRL for As imposed by the Chinese government is $100 \mu \mathrm{g} / \mathrm{kg}$ (CFDA\&NHC, 2017). The measurements for As were never higher than this threshold for all studied samples. To our knowledge, no MRL for Cd in raw milk exists. However, Cd globally had the highest positive rate (77.4\%) showing a strong presence of $\mathrm{Cd}$ in the studied raw milk. Lead and As had a global lower positive rate: $68.4 \%$ and $46.5 \%$, respectively (Table 1 ).

\subsection{Between area variability}

The positive rate differed between studied regions. The highest positive rate for Pb was observed for area G (96\%), followed by areas J (91\%) and $\mathrm{A}(90 \%)$. The lowest was measured in area I (40\%). Area J had the highest positive rate for As (66\%) and area E the lowest (28\%). For Cd, the highest positive rate was observed for area A (98\%) and the lowest for area $C(55 \%)$. The ranges observed for the positive rate were different between heavy metals: $68.4 \%$ for $\mathrm{Pb}, 46.5 \%$ for $\mathrm{As}$, and $77.4 \%$ for $\mathrm{Cd}$.

Differences in the contents of $\mathrm{Pb}, \mathrm{As}$, and Cd were also observed between areas (Table 1). Kruskal-Wallis tests were performed to evaluate the significance of these differences between regions. The obtained $P$ values confirmed the existence of significant differences between areas. Lead content in area $G$ was significantly $(P<0.05)$ different between all areas except $A$ and J. Furthermore, areas $C$ and I showed no difference $(P>0.05)$ with area $H$, nor between areas $C$ and I. There were no significant differences in $\mathrm{Pb}$ content in areas $\mathrm{A}, \mathrm{J}$, and $\mathrm{E}(P>0.05)$. The mean value of As in area J was significantly higher than areas $C, D, E, F$, and I $(P<0.05)$. The contents of $C d$ in area A showed a significant difference with all other areas, followed by areas J and $G(P<0.01)$.

\subsection{Within area variability}

For all studied heavy metals, the standard deviations observed within area were higher than those observed between areas (Table 1). To study the spatial distribution of this contamination in more detail, the levels of $\mathrm{Pb}, \mathrm{As}$, and $\mathrm{Cd}$ measured in milk samples were modelled using the ordinary kriging method (Figs. 2 to 4 ).

Arsenic and Cd in raw milk from area A shared a similar pattern of higher levels in western areas, and $\mathrm{Pb}$ showed higher levels in the northwest. Lead and As in raw milk from area $C$ present the same spatial distribution trait of decreasing from northeast to southwest, while $\mathrm{Cd}$ showed a different distribution from $\mathrm{Pb}$ and As. Arsenic and $\mathrm{Cd}$ in area $\mathrm{F}$ presented same pattern with higher concentrations in the north, whereas $\mathrm{Pb}$ in raw milk had a different distribution pattern with higher 
Table 1

Descriptive statistics of $\mathrm{Pb}, \mathrm{As}$, and Cd contents measured in raw cow milk from the 10 main milk producing areas in China ( $N=997$ samples).

\begin{tabular}{|c|c|c|c|c|c|c|c|c|c|}
\hline & \multicolumn{3}{|l|}{$\mathrm{Pb}(\mu \mathrm{g} / \mathrm{L})$} & \multicolumn{3}{|l|}{ As $(\mu \mathrm{g} / \mathrm{L})$} & \multicolumn{3}{|l|}{$\mathrm{Cd}(\mu \mathrm{g} / \mathrm{L})$} \\
\hline & Mean $^{\mathrm{a}} \pm \mathrm{SD}$ & Range & Positive rate ${ }^{\mathrm{b}}$ & Mean \pm SD & Range & Positive rate & Mean \pm SD & Range & Positive rate \\
\hline A & $2.11 \pm 2.37$ & $0.14-19.62$ & $90.00 \%$ & $0.27 \pm 0.36$ & $0.05-2.17$ & $58.00 \%$ & $0.09 \pm 0.07$ & $0.001-0.39$ & $98.00 \%$ \\
\hline B & $1.43 \pm 2.26$ & $0.14-16.15$ & $66.00 \%$ & $0.51 \pm 0.90$ & $0.05-6.21$ & $46.00 \%$ & $0.02 \pm 0.03$ & $0.001-0.20$ & $59.00 \%$ \\
\hline C & $1.60 \pm 5.39$ & $0.14-38.61$ & $42.00 \%$ & $0.33 \pm 1.59$ & $0.05-15.77$ & $49.00 \%$ & $0.07 \pm 0.10$ & $0.001-0.36$ & $55.00 \%$ \\
\hline D & $2.73 \pm 5.92$ & $0.14-36.73$ & $60.00 \%$ & $0.14 \pm 0.18$ & $0.05-0.94$ & $35.00 \%$ & $0.05 \pm 0.09$ & $0.001-0.54$ & $72.00 \%$ \\
\hline $\mathrm{E}$ & $2.96 \pm 6.66$ & $0.14-35.74$ & $82.80 \%$ & $0.34 \pm 1.05$ & $0.05-9.12$ & $28.00 \%$ & $0.04 \pm 0.05$ & $0.001-0.21$ & $59.00 \%$ \\
\hline $\mathrm{F}$ & $1.35 \pm 1.77$ & $0.14-9.70$ & $76.00 \%$ & $0.13 \pm 0.12$ & $0.05-0.68$ & $44.00 \%$ & $0.02 \pm 0.02$ & $0.001-0.09$ & $82.00 \%$ \\
\hline G & $2.01 \pm 1.16$ & $0.14-6.45$ & $96.00 \%$ & $0.17 \pm 0.24$ & $0.05-1.90$ & $51.00 \%$ & $0.05 \pm 0.04$ & $0.001-0.18$ & $92.00 \%$ \\
\hline $\mathrm{H}$ & $1.16 \pm 3.16$ & $0.14-28.94$ & $41.20 \%$ & $0.19 \pm 0.27$ & $0.05-1.93$ & $45.40 \%$ & $0.03 \pm 0.03$ & $0.001-0.17$ & $74.20 \%$ \\
\hline I & $0.46 \pm 0.62$ & $0.14-4.19$ & $40.00 \%$ & $0.18 \pm 0.33$ & $0.05-2.96$ & $43.00 \%$ & $0.03 \pm 0.03$ & $0.001-0.12$ & $89.00 \%$ \\
\hline $\mathrm{J}$ & $1.70 \pm 1.39$ & $0.14-8.73$ & $91.00 \%$ & $0.80 \pm 2.27$ & $0.05-15.18$ & $66.00 \%$ & $0.06 \pm 0.09$ & $0.001-0.69$ & $94.00 \%$ \\
\hline Total & $1.75 \pm 3.73$ & 014-38.61 & $68.40 \%$ & $0.31 \pm 1.02$ & $0.05-15.77$ & $46.50 \%$ & $0.05 \pm 0.07$ & $0.001-0.69$ & $77.40 \%$ \\
\hline
\end{tabular}

a Mean values is calculate by all samples, concentrations below the limit of detection were replaced by half the value of the LOD.

b Positive rate is the sample number that values upper than LOD divided total samples' number.

concentrations in the east region. In addition, $\mathrm{Pb}, \mathrm{As}$, and $\mathrm{Cd}$ in area $\mathrm{G}$ showed a similar southwest to northeast distribution trend with higher concentrations in the southwest, whereas $\mathrm{Pb}$ also showed higher levels in the north region. In area $\mathrm{I}, \mathrm{Pb}, \mathrm{As}$, and $\mathrm{Cd}$ showed the same higher concentration in the southeast. The distribution properties of $\mathrm{Pb}, \mathrm{As}$, and $\mathrm{Cd}$ in areas $\mathrm{B}$ and $\mathrm{D}$ presented a similar trend with higher contents in the mid and west. However, the distribution pattern of $\mathrm{Pb}, \mathrm{As}$, and $\mathrm{Cd}$ in area $\mathrm{E}, \mathrm{H}$, and $\mathrm{J}$ showed a different trend. The higher levels of these metals were concentrated in limited ranges.

The statistical parameters calculated from the cross-validation procedure are given in Table 2 . The mean value for MSE was -0.004 for $\mathrm{Pb}, 0.001$ for As, and 0.004 for $\mathrm{Cd}$. Throughout the studied traits, the MSE in absolute values varied between 0.000 and 0.043 . For all studied heavy metals, the values of RMSSE- 1 changed between regions. Globally, throughout the studied metals, half of the RMSSE- 1 estimations
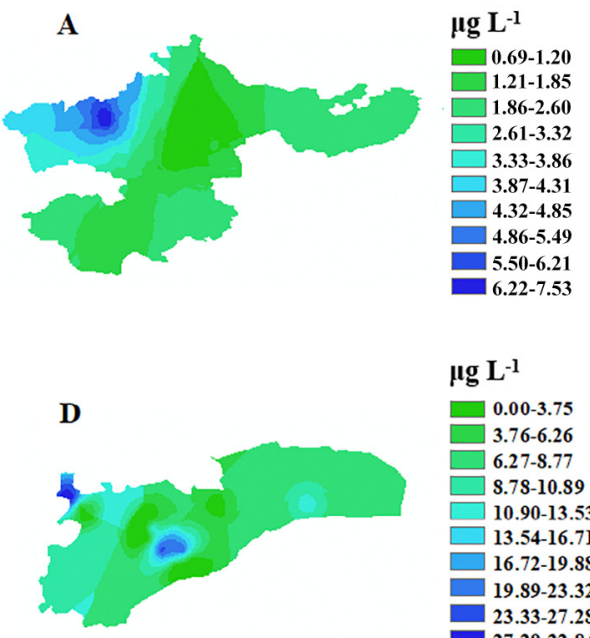

$\mu g L^{-1}$
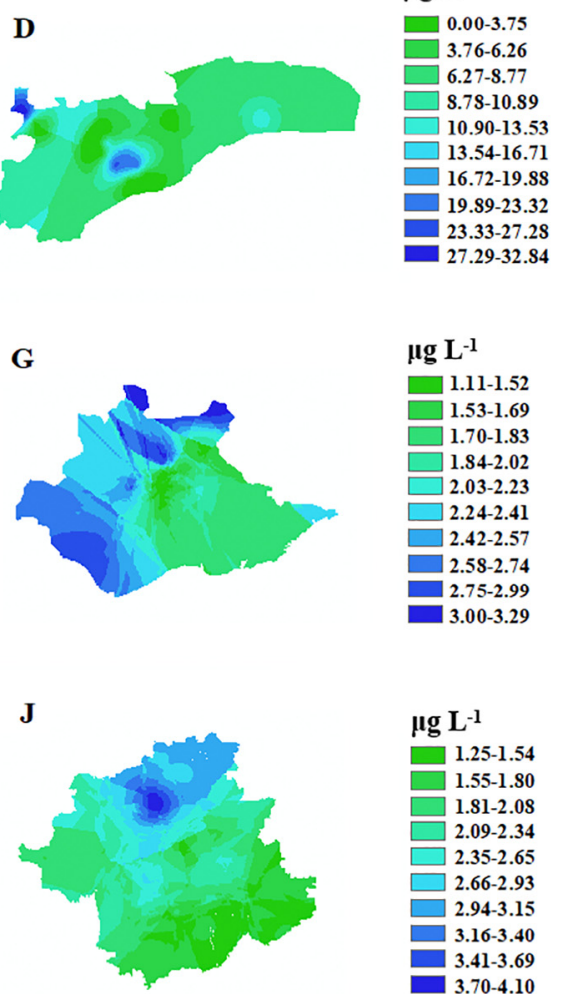

$\mu g \mathbf{L}^{-1}$

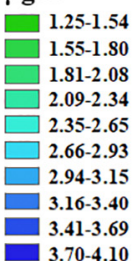

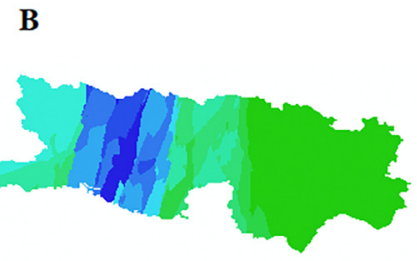

$\mu g \mathbf{L}^{-1}$

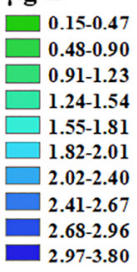

$\mu g L^{-1}$
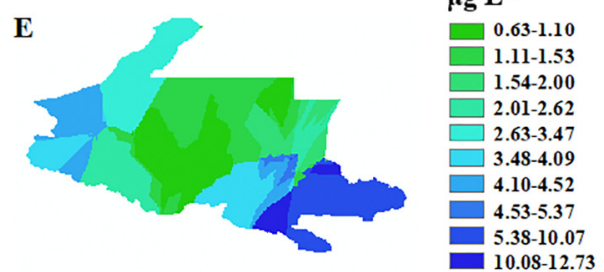

$\mathbf{H}$

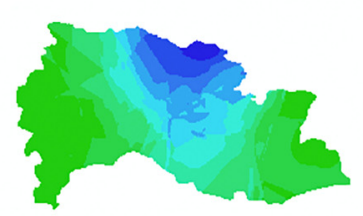

$\mu \mathrm{g} \mathbf{L}^{-1}$

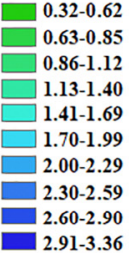

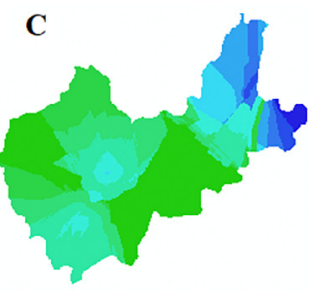

$\mu g \mathbf{L}^{-1}$

0.16-0.75

0.76-1.32

1.33-1.84

1.85-2.39

3.10-3.66

$3.67-4.07$
$\square$

4.08-4.53

4.54-5.09

5.10-5.96

$\operatorname{\mu g} \mathrm{L}^{-1}$

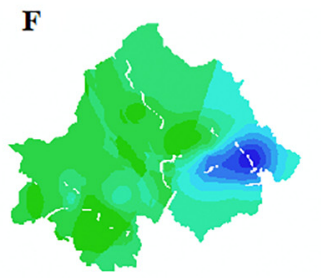

0.35-1.11

\begin{tabular}{|r|}
\hline \\
$0.35-1.11$ \\
\hline \\
$1.12-1.58$
\end{tabular}

$1.59-2.20$

2.21-2.83

-

3.33-3.95

3.96-4.60

4.61-5.20

5.21-5.85

$5.86-6.99$

I

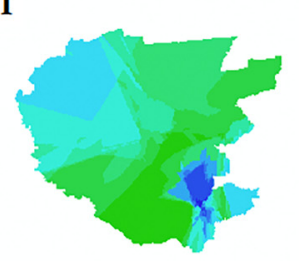

$\lg \mathrm{L}^{-1}$

0.14-0.20

\begin{tabular}{|r}
- \\
$\square$ \\
\hline
\end{tabular}

$\square$ 0.31-0.37

0.38-0.44

0.45- 0.50

$\square 0.51-0.59$

$0.51-0.59$

0.60-0.69

0.70-0.76

0.77-0.82

Fig. 2. Spatial distribution of the lead concentrations in raw milk $(\mu \mathrm{g} / \mathrm{L})$ in the main milk producing areas in China. 


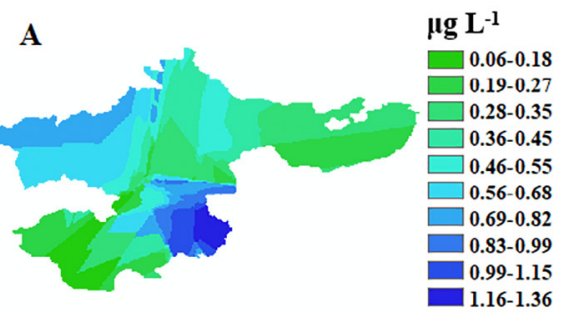

D

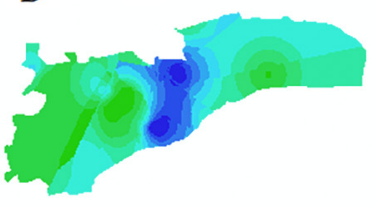

G

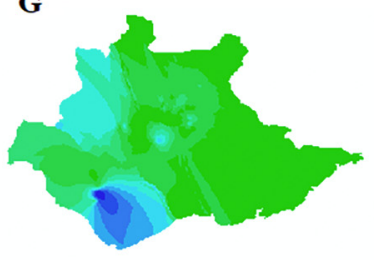

$\mathbf{J}$

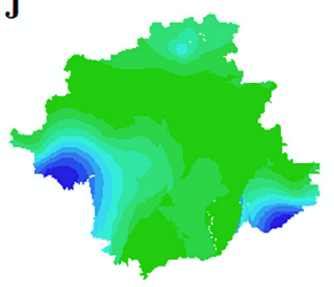

$\mu g L^{-1}$

$\square$ 0.06-0.08

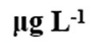

0.20-0.33

$0.34-0.46$
$\square$

$0.47-0.59$
$\square$

$\square$ 0.60-0.74

0.75-0.89

0.90-1.03

1.04-1.28

1.29-1.87 $\operatorname{\mu g} \mathrm{L}^{-1}$

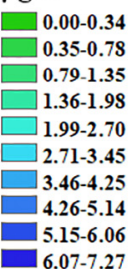

B

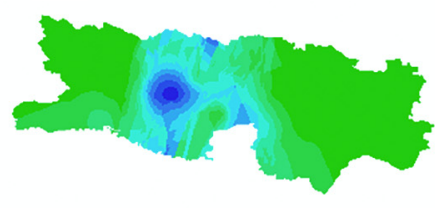

0.081-0.099

0.100-0.115

0.116-0.128

0.129-0.142

0.143-0.160

0.161-0.181

0.182-0.202

0.203-0.222

0.223-0.267

0.000-0.095

0.096-0.199

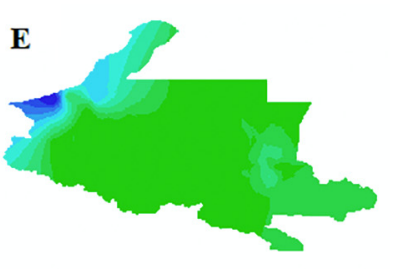

H

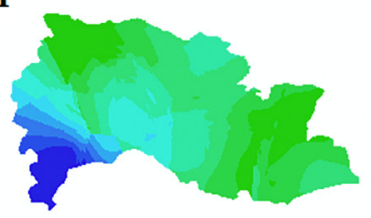

$\mu g L^{-1}$

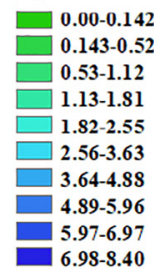

$\mu g \mathbf{L}^{-1}$
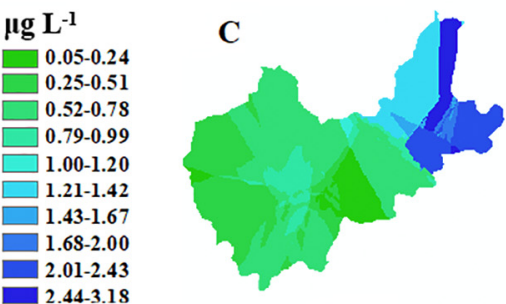

$\mu g \mathrm{~L}^{-1}$

0.07-0.098

0.099-0.13

$\square$ 0.14-0.16

$\square$ 0.17-0.22

$\square$ 0.23-0.26

$\square$ 0.27-0.50

$\square$ 0.51-1.45

$\square$ 1.46-1.47

$1.48-1.59$

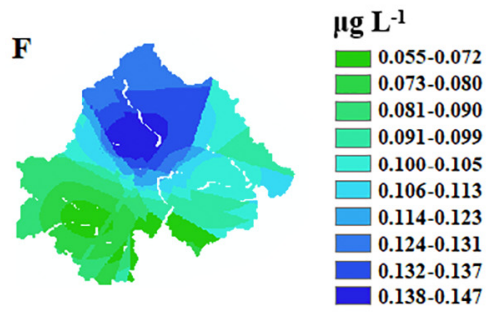

$\mu g \mathrm{~L}^{-1}$

0.07-0.11

$\begin{array}{r}0.07-0.11 \\ \hline \quad 0.12-0.15\end{array}$

0.15-0.20

$0.21-0.25$

0.26-0.32

0.33-0.39

0.40-0.46

0.47-0.53

0.54-0.61

0.62-0.69 $\mu g L^{-1}$

I

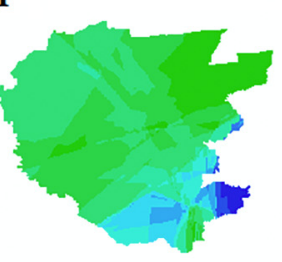

0.06-0.09

0.10-0.13

0.14-0.18

$\square$ 0.19-0.22

$\square$ 0.23-0.25

$\square$ 0.26-0.2s

$\square$ 0.29-0.34

0.35-0.42

0.43-0.49

$0.43-0.49$
$0.50-0.52$

Fig. 3. Spatial distribution of the arsenic concentrations in raw milk $(\mu \mathrm{g} / \mathrm{L})$ in the main milk producing areas in China.

were negative. A total of 15 absolute values of RMSSE- 1 were lower than 0.1 suggesting a good representation of the uncertainty. This represented $50 \%$ for $\mathrm{Pb}, 40 \%$ for As, and $60 \%$ for Cd. An extremely high RMSSE-1 value was observed for the As model in area E. A high value was also observed for the As model in area G.

\subsection{Correlations between $\mathrm{Pb}, \mathrm{As}$, and $\mathrm{Cd}$}

Spearman correlations calculated from measured $\mathrm{Pb}, \mathrm{As}$, and $\mathrm{Cd}$ contents within specific areas are presented in Table 3. Lead and Cd showed significant positive correlations for all studied areas, except area I where the correlation value was positive but not significant. Lead-As showed positive correlations for areas $\mathrm{A}, \mathrm{B}, \mathrm{C}, \mathrm{H}$, and J. The remaining correlations were also positive for areas $D, E$, and $G$, and slightly negative for areas $\mathrm{F}$ and I, but all of those values were not significantly different to zero. Positive correlations were also found for As-Cd in areas E, F, G, H, $\mathrm{I}$, and J. Positive correlations were observed between As and $\mathrm{Cd}$ in areas $A$ and $C$ but were not significant. No significant negative correlations were observed for areas B and D.

Based on the significance levels, we can observe that areas A, B, and C seemed to have similar relationships between $\mathrm{Pb}-\mathrm{As}$ and $\mathrm{Pb}-\mathrm{Cd}$. Areas $\mathrm{E}$, $\mathrm{F}$, and $\mathrm{G}$ also showed similar correlations for $\mathrm{As}-\mathrm{Cd}$ and $\mathrm{Pb}-\mathrm{Cd}$. Areas $\mathrm{H}$ and $\mathrm{J}$ seemed to also have similar relationship patterns between $\mathrm{Pb}$ -
As, Pb-Cd, and As-Cd. Areas D and I were different to the other studied areas.

\section{Discussion}

Although milk and dairy products contain many active biomolecules for human health, these food products can also contain unfavourable components such as $\mathrm{Pb}, \mathrm{As}$, and $\mathrm{Cd}$. However, the presence of $\mathrm{Pb}, \mathrm{As}$, and $\mathrm{Cd}$ are related to the production environment of the milk. The current large scale study allows observing large variability of heavy metal contamination in milk within and between the main ten Chinese milk producing areas. Those results suggest to develop appropriate sampling procedures in order to control the evolution of this contamination of milk, which is potentially dangerous for human health as well as for dairy cows.

The presence of $\mathrm{Pb}$ and $\mathrm{Cd}$ was observed in the majority of analysed milk samples: $68.4 \%$ for $\mathrm{Pb}$, and $77.4 \%$ for $\mathrm{Cd}$. This positive rate was slightly lower for As with a percentage equal to $46.5 \%$. This means that these heavy metals are largely present in milk. Some sources of contamination therefore exist in the studied milk production areas. However, there are 3, 3, 5, and 1 samples from area C, D, E, and $\mathrm{H}$ were higher than the MRL imposed by European Union. This second observation allows a nuanced conclusion of the observed positive rate to be made. 


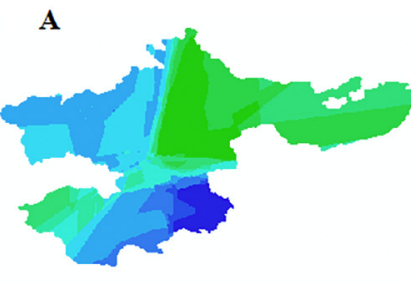

$\operatorname{lng} \mathrm{I}^{-1}$

$\square$ 0.047-0.060

0.061-0.069

$\square .070-0.080$

$\square$ 0.081-0.092

$\square$ 0.093-0.105

$\square$ 0.106-0.117

$0.118-0.128$

0.129-0.144

0.145-0.167

0.168-0.201

$\mu \operatorname{g~L} \mathbf{L}^{-1}$
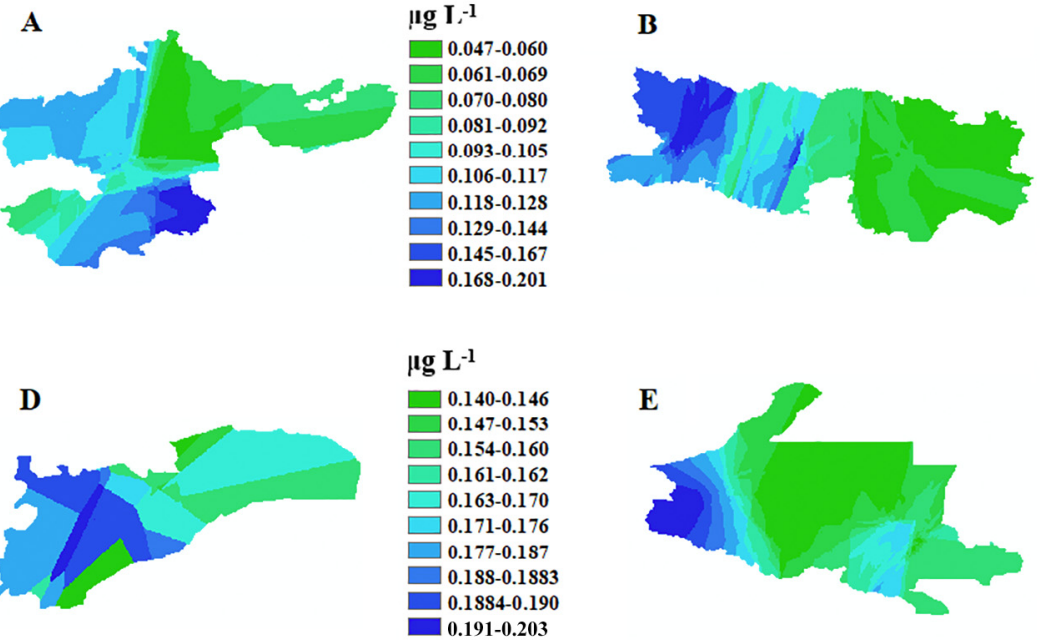

$\mu \mathrm{g} \mathrm{L}^{-1}$

0.005-0.009 $\square \quad 0.010-0.013$

0.019-0.024

0.025-0.02s

$0.029-0.033$
0.034

$\begin{array}{r}0.029-0.033 \\ \hline\end{array}$

0.037-0.039

0.040-0.044

0.045-0.049

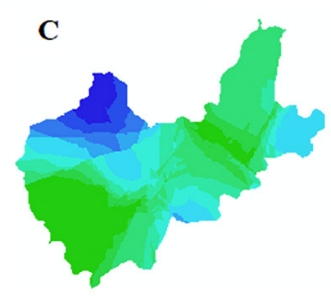

$\boldsymbol{\mu} \mathbf{g} \mathrm{L}^{-1}$

- $0.015-0.031$

0.032-0.053

0.054-0.073

$\square$ 0.074-0.091

$\square$ 0.092-0.111

$\square$ 0.112-0.136

0.137-0.161

0.162-0.187

0.18s- 0.214

0.215-0.240

\section{Ig $L^{-1}$}
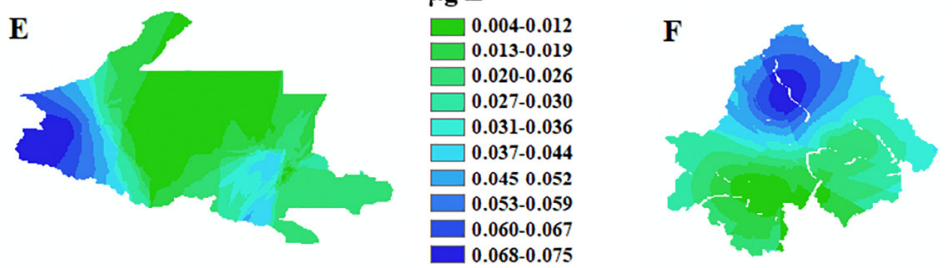

$\mu \mathrm{g} \mathrm{L}^{-1}$

0.008-0.013

0.014-0.017

$0.018-0.020$

0.021-0.024

$\begin{array}{r}0.021-0.024 \\ 0.025-0.028 \\ \hline\end{array}$

0.029-0.032

$\square$ 0.033-0.037

0.038-0.041

0.042-0.045

0.046-0.050

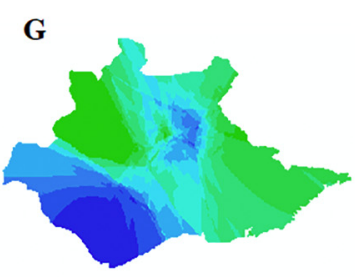

$\operatorname{\mu g} \mathrm{L}^{-1}$

0.023-0.031

0.032-0.039

0.040-0.045

- 0.046-0.051

0.052-0.058

0.059-0.064

0.065-0.073

0.074-0.082

0.083-0.089

0.090-0.098

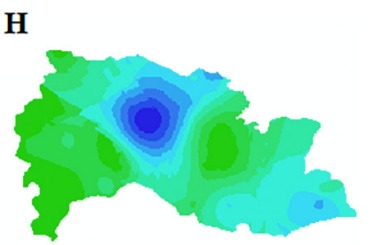

$\operatorname{\mu g} \mathrm{L}^{-1}$

0.019-0.02s

$0.029-0.036$

0.037-0.045

0.046-0.053

0.054-0.062

0.063-0.070

0.071-0.079

0.080-0.091

0.092-0.104

0.105-0.124
I

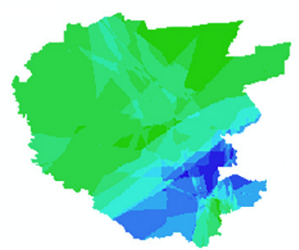

$\mu g L^{-1}$

0.016-0.020

0.021-0.024

$\square$ 0.025-0.028

$\square \quad 0.029-0.033$

$\square$ 0.034-0.038

$\square$ 0.039-0.041

$\square 0.042-0.045$

0.046-0.049

0.050-0.053

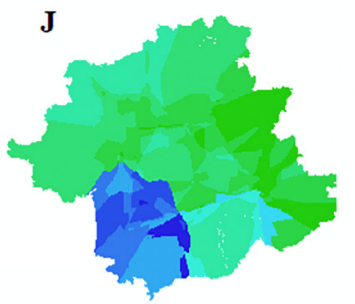

$\mu g L^{-1}$

$0.038-0.046$

0.047-0.053

0.054-0.060

0.061-0.067

$0.068-0.074$

$\square \quad 0.075-0.035$

0.099-0.105

0.106-0.115

0.116-0.133

Fig. 4. Spatial distribution of the cadmium concentrations in raw milk $(\mu \mathrm{g} / \mathrm{L})$ in the main milk producing areas in China.

Therefore, $\mathrm{Pb}$ and As were present in many measured samples but the contents are less likely to lead to serious health problems as they have globally low contents of these heavy metals. The mean value observed for As was lower than that reported by Pérez-Carrera et al. (2016) in Argentina $(4.0 \mu \mathrm{g} / \mathrm{kg}, 3.5 \mu \mathrm{g} / \mathrm{kg})$ and by Sarkar et al. (2016) in India where the cows were highly contaminated with As $(69 \mu \mathrm{g} / \mathrm{L})$. The average levels of $\mathrm{Pb}$ in the present study were also lower than those recorded by Bilandzic et al. (2016) in rural areas in Croatia $(11.4 \mu \mathrm{g} / \mathrm{kg}$, range $5.11-131 \mu \mathrm{g} / \mathrm{kg})$ and by Kazi et al. (2009) in Pakistan $(47.6 \mu \mathrm{g} / \mathrm{L}$, range 41.8-58.7 $\mu \mathrm{g} / \mathrm{L}$ ). The observed mean $\mathrm{Pb}$ value was similar to that obtained by Kim et al. (2016) in Korea (1.48 $\mu \mathrm{g} / \mathrm{kg}$ ) and by Tang et al. (2014) in China. Unfortunately no MLR is available for Cd but the measured content $(0.06 \mu \mathrm{g} / \mathrm{L})$ was globally quite low when compared with the literature (Ismail et al. (2015): $1.0 \mu \mathrm{g} / \mathrm{kg}$; Kazi et al. (2009): 44.2 $\mu \mathrm{g} / \mathrm{L}, 42.9-60.2 \mu \mathrm{g} / \mathrm{L}$; Tang et al. (2014): $2 \mu \mathrm{g} / \mathrm{kg}$ ). One sample from area J had an extremely high value for $\mathrm{Cd}(8.74 \mu \mathrm{g} / \mathrm{L})$. This is much higher than other values and a future investigation must be conducted to confirm this extreme value.

The positive rate as well as the measured contents for the studied heavy metals differed between regions. This could explain the

Table 2

Root mean squared error (RMSE), mean of standardised error (MSE), and root mean squared standardised error (RMSS) obtained after a k-fold cross-validation for each studied area.

\begin{tabular}{|c|c|c|c|c|c|c|c|c|c|}
\hline \multirow[b]{2}{*}{ Area } & \multicolumn{3}{|c|}{$\mathrm{Pb}(\mu \mathrm{g} / \mathrm{L})$} & \multicolumn{3}{|c|}{ As $(\mu \mathrm{g} / \mathrm{L})$} & \multicolumn{3}{|c|}{$\mathrm{Cd}(\mu \mathrm{g} / \mathrm{L})$} \\
\hline & RMSE & MSE & RMSSE-1 & RMSE & MSE & RMSSE-1 & RMSE & MSE & RMSSE-1 \\
\hline A & 2.255 & 0.004 & 0.191 & 0.334 & 0.009 & -0.053 & 0.064 & -0.024 & 0.190 \\
\hline B & 3.463 & -0.012 & -0.225 & 0.893 & -0.002 & -0.006 & 0.050 & -0.020 & 0.157 \\
\hline C & 5.139 & -0.022 & -0.120 & 2.185 & 0.000 & -0.142 & 0.098 & 0.004 & -0.102 \\
\hline D & 6.053 & -0.010 & -0.224 & 0.186 & 0.000 & -0.081 & 0.090 & -0.043 & -0.093 \\
\hline E & 7.082 & 0.013 & 0.047 & 1.257 & -0.021 & 1.011 & 0.041 & 0.034 & -0.331 \\
\hline $\mathrm{F}$ & 1.797 & -0.003 & 0.024 & 0.085 & 0.000 & -0.405 & 0.017 & 0.024 & -0.088 \\
\hline G & 1.148 & -0.009 & 0.037 & 0.325 & 0.033 & 0.620 & 0.037 & 0.024 & -0.064 \\
\hline $\mathrm{H}$ & 3.151 & 0.011 & -0.081 & 0.273 & -0.007 & -0.005 & 0.036 & 0.020 & 0.062 \\
\hline I & 0.777 & 0.003 & -0.232 & 0.347 & -0.005 & 0.167 & 0.027 & 0.012 & 0.043 \\
\hline $\mathrm{J}$ & 1.491 & -0.014 & 0.002 & 2.311 & 0.004 & 0.284 & 0.106 & 0.006 & -0.043 \\
\hline
\end{tabular}


Table 3

Spearman correlations between $\mathrm{Pb}-\mathrm{As}, \mathrm{Pb}-\mathrm{Cd}$, and As- $\mathrm{Cd}$ milk concentrations $(\mu \mathrm{g} / \mathrm{L})$ in the ten main milk producing areas in China (A-J).

\begin{tabular}{llll}
\hline area & $\mathrm{Pb}-\mathrm{As}$ & $\mathrm{Pb}-\mathrm{Cd}$ & $\mathrm{As}-\mathrm{Cd}$ \\
\hline $\mathrm{A}$ & $0.20^{*}$ & $0.36^{* *}$ & 0.19 \\
$\mathrm{~B}$ & $0.31^{* *}$ & $0.33^{* *}$ & -0.16 \\
$\mathrm{C}$ & $0.28^{* *}$ & $0.32^{* *}$ & 0.05 \\
$\mathrm{D}$ & 0.03 & $0.38^{* *}$ & -0.15 \\
$\mathrm{E}$ & 0.14 & $0.46^{* *}$ & $0.22^{*}$ \\
$\mathrm{~F}$ & -0.09 & $0.30^{* *}$ & $0.41^{* *}$ \\
$\mathrm{G}$ & 0.18 & $0.31^{* *}$ & $0.51^{* *}$ \\
$\mathrm{H}$ & $0.48^{* *}$ & $0.48^{* *}$ & $0.21^{*}$ \\
$\mathrm{I}$ & -0.07 & 0.11 & $0.32^{* *}$ \\
$\mathrm{~J}$ & $0.52^{* *}$ & $0.60^{* *}$ & $0.43^{* *}$ \\
\hline$* \mathrm{P}<0.05$ & & & \\
$* *$ & & &
\end{tabular}

differences observed between these results and the studies by Tang et al. (2014) and Zhou et al. (2016) who also conducted studies in China. As mentioned previously, the results obtained by Tang et al. (2014) from Chinese regions showed similar values for $\mathrm{Pb}$ and higher values for $\mathrm{Cd}$. In this latter study, the samples were collected in Zhejiang province which is close to areas $\mathrm{D}$ and $\mathrm{J}$ of the present study. Area J showed an extremely high variability for $\mathrm{Cd}$ content which can relate to the higher value observed by Tang et al. (2014) from a lower number of samples. Zhou et al. (2016) observed a higher positive rate for As (82.5\%) and a lower rate for Cd (32.5\%). In Zhou et al. (2016), only 40 raw cow milk samples were collected in two regions (20 samples per region instead of 100 in the present study). Significant differences in the levels of $\mathrm{Pb}, \mathrm{As}$, and $\mathrm{Cd}$ between the main Chinese milk producing regions were confirmed in this study. However, based on the standard deviation observed in this study, we can suggest a higher heterogeneity of milk heavy metal contamination within areas than between areas. This was expected as the contamination of milk by heavy metals is mainly due to contamination of the environment and also the contamination of fodder given to the dairy cows (Mohajeri et al., 2014; Shailaja et al., 2014). For instance, the proximity of lead zinc factories favoured contamination (Mohajeri et al., 2014; Patra et al., 2008; Swarup et al., 2005). These last authors found that the mean blood $\mathrm{Pb}$ level in cows around the smelter was higher $(1.09 \pm 0.26 \mathrm{mg} / \mathrm{L})$ than the cows from the reference area $(0.72 \pm 0.25 \mathrm{mg} / \mathrm{L})$. Higher As $(65 \%$ detectable residue) concentrations in milk found in the winter sampling are possibly related to a higher consumption of concentrate in the feed, and soil ingestion when grazing (Rey-Crespo et al., 2013). The contents of As in industrial regions close to the Black Sea had higher levels, whereas regions also near the Black Sea but far from the industrial region showed higher Pb levels (Temiz and Soylu, 2012). The steel industry and traffic activities also lead to $\mathrm{Cd}$ and $\mathrm{Pb}$ pollution (Qing et al., 2015). A previous study indicated that the lower reach of the Yellow River near Inner Mongolia contains higher metal concentrations in comparison with the middle and upper reaches of the river near Ningxia and Gansu, China (Ma et al., 2016). The spatial distribution of Cd in wheat grains showed similar geographical patterns with soils, whereas $\mathrm{Pb}$ showed an opposite pattern (Ran et al., 2016). All these results indicate that conditions in the local environment, such as those of the soil, water, river, industry, mining, and smelting, may contribute to $\mathrm{Pb}, \mathrm{As}$, and $\mathrm{Cd}$ contamination in animals and its transferrence to milk.

As it is not possible to make a sampling collection among all potential pollutant industries, there is an interest in realising a primary screening of the variability of milk heavy metal contamination. This was the objective of this study and this explains why we have decided to randomly select the studied farms. Based on the nearly 1000 measured samples and by using an ordinary kriging method, it was possible to model the distribution of $\mathrm{Pb}, \mathrm{As}$, and $\mathrm{Cd}$ contamination in milk in all studied areas (Figs. 2 to 4 ). The cross-validation confirmed that the predictions were mainly unbiased. However, an uncertainty was observed for some models. A little over half of the estimated RMSSE-1 values were lower than 0.01 suggesting good modelling of data. The predictions obtained in some regions overestimated or underestimated the variability of the considered contamination. This is related to an inappropriate sampling procedure, but this cannot be known before making the different measurements realised in this study. However, the distribution map presented in this study, although imperfect, could be used to define a more appropriate sampling procedure if we want to control the evolution of milk heavy metal contamination in China in the future.

Based on Table 2, we can see that there are no values of RMSSE-1 lower than 0.001 for the 3 metals modelled in the same region. This could indicate different behaviours of $\mathrm{Pb}$, As, and $\mathrm{Cd}$ milk contamination. This was confirmed by the estimation of Spearman correlations between all studied heavy metals per area. The values were globally moderate positive, some were negative but these values were not significant. Therefore a moderate relationship exists between the studied metals. However, the values of this correlation changed between the studied regions. A hypothesis should be that the sources of contamination are different between regions. Pilarczyk et al. (2013) also found significant positive correlations between the concentrations of $\mathrm{Pb}$ and $\mathrm{Cd}$ in the milk of Simmental and Holstein-Friesian cows $(r=0.86, r=$ 0.87 ). These correlations were also visible on the obtained distribution maps (Figs. 2 to 4 ).

\section{Conclusion}

Lead, As, and Cd were measured in many analysed samples. However their average contents were lower than those reported in the literature. Moreover, no samples had a content of $\mathrm{Pb}$ and As higher than the MRL imposed by the Chinese Government. The heterogeneity of milk heavy metal contamination was higher within areas than between areas. Significant differences were observed between regions. Spatial distribution concentrations in raw milk samples were modelled using an ordinary kriging method to illustrate the distribution of milk $\mathrm{Pb}, \mathrm{As}$, and Cd contamination. Unfortunately, for a little $<50 \%$ of the developed models, the cross-validation results showed a moderate uncertainty leading to an overestimation or an underestimation of the variability of those contaminates by the predictions. This was explained by the sampling procedure used. As no information was available about the potential pollution with $\mathrm{Pb}, \mathrm{As}$, and $\mathrm{Cd}$, a random selection was done by farm. This was therefore not appropriate enough for some models. In the future, the distribution maps created in this study could be used to better define the sampling procedure needed. This could allow a programme to be implemented to follow the evolution of this contamination in milk in the main milk producing areas in China.

\section{Conflict of interest statement}

All authors have approved the submission and none of the author declares any conflict of interest in the work performed or in the submission of the manuscript.

\section{Acknowledgements}

This study was financially supported by the Project of Risk Assessment on Raw Milk (GJFP2017008), the Special Fund for Agro-scientific Research in the Public Interest (201403071), the National Dairy Industry and Technology System (CARS-36), and the Agricultural Science and Technology Innovation Program (ASTIP-IAS12).

\section{References}

Alasalvara, C., Taylora, K.D.A., Zubcovb, E., Shahidic, F., Alexisd, M., 2002. Differentiation of cultured and wild sea bass (Dicentrarchus labrax): total lipid content, fatty acid and trace mineral composition. Food Chem. 79, 145-150.

Bilandzic, N., Sedak, M., Calopek, B., Luburic, D.B., Solomun Kolanovic, B., Varenina, I., Dokic, M., Kmetic, I., Murati, T., 2016. Lead concentrations in raw cow and goat 
milk collected in rural areas of Croatia from 2010 to 2014. Bull. Environ. Contam. Toxicol. 96 (5), 645-649.

CFDA\&NHC, 2017. Maximum Levels of Contaminants in Foods. Vol. GB 2762. China Food and Drug Adiministration; National Health Commission of the People's Republic of China, China.

EC, 2015. Commossion regulation (EU) 2015/1005 amending regulation (EC) no 1881/ 2006 as regards maximum levels of lead in certain foodstuffs. Off. J. Eur. Union 161, 11.

Ismail, A., Riaz, M., Akhtar, S., Ismail, T., Ahmad, Z., Hashmi, M.S., 2015. Estimated daily intake and health risk of heavy metals by consumption of milk. Food Addit. Contam. Part B Surveill. 8 (4), 260-265.

Kazi, T.G., Jalbani, N., Baig, J.A., Kandhro, G.A., Afridi, H.I., Arain, M.B., Jamali, M.K., Shah, A.Q., 2009. Assessment of toxic metals in raw and processed milk samples using electrothermal atomic absorption spectrophotometer. Food Chem. Toxicol. 47 (9) 2163-2169.

Kim, D.-G., Kim, M., Shin, J.Y., Son, S.-W., 2016. Cadmium and lead in animal tissue (muscle, liver and kidney), cow milk and dairy products in Korea. Food Addit. Contam. Part B Surveill. 9 (1), 33-37.

Licata, P., Di Bella, G., Potorti, A. G., Lo Turco, V., Salvo, A., \& Dugo, G. M., 2012. Determination of trace elements in goat and ovine milk from Calabria (Italy) by ICP-AES. Food Addit. Contam. Part B Surveill., 5(4), 268-271.

Ma, X., Zuo, H., Tian, M., Zhang, L., Meng, J., Zhou, X., Min, N., Chang, X., Liu, Y., 2016. Assessment of heavy metals contamination in sediments from three adjacent regions of the Yellow River using metal chemical fractions and multivariate analysis techniques. Chemosphere 144, 264-272.

Malhat, F., Hagag, M., Saber, A., Fayz, A.E., 2012. Contamination of cows milk by heavy metal in Egypt. Bull. Environ. Contam. Toxicol. 88 (4), 611-613.

Mohajeri, G., Norouzian, M.A., Mohseni, M., Afzalzadeh, A., 2014. Changes in blood metals, hematology and hepatic enzyme activities in lactating cows reared in the vicinity of a lead-zinc smelter. Bull. Environ. Contam. Toxicol. 92 (6), 693-697.

Ohno, K., Yanase, T., Matsuo, Y., Kimura, T., Rahman, M.H., Magara, Y., Matsui, Y., 2007. Arsenic intake via water and food by a population living in an arsenic-affected area of Bangladesh. Sci. Total Environ. 381 (1-3), 68-76.

Oliver, M.A., 1997. Soil and human health: a review. Eur. J. Soil Sci. 48 (4), 573-592.

Patra, R.C., Swarup, D., Kumar, P., Nandi, D., Naresh, R., Ali, S.L., 2008. Milk trace elements in lactating cows environmentally exposed to higher level of lead and cadmium around different industrial units. Sci. Total Environ. 404 (1), 36-43.

Pérez-Carrera, A.L., Arellano, F.E., Fernández-Cirelli, A., 2016. Concentration of trace elements in raw milk from cows in the southeast of Córdoba province, Argentina. Dairy Sci. Technol. 96 (5), 591-602.
Pilarczyk, R., Wojcik, J., Czerniak, P., Sablik, P., Pilarczyk, B., Tomza-Marciniak, A., 2013. Concentrations of toxic heavy metals and trace elements in raw milk of Simmental and Holstein-Friesian cows from organic farm. Environ. Monit. Assess. 185 (10), 8383-8392.

Potortì, A.G., Bella, G.D., Turco, V.L., Rando, R., Dugo, G., 2013. Non-toxic and potentially toxic elements in Italian donkey milk by ICP-MS and multivariate analysis. J. Food Compos. Anal. 31 (1), 161-172.

Qing, X., Yutong, Z., Shenggao, L., 2015. Assessment of heavy metal pollution and human health risk in urban soils of steel industrial city (Anshan), Liaoning, Northeast China. Ecotoxicol. Environ. Saf. 120, 377-385.

Qu, X.Y., Zheng, B.Q., Zheng, N., Wang, J.Q., Xu, X.M., Han, R.W., Zhen, Y.P., Li, S.L., 2013. Survey of heavy metal residues in raw milk in Tangshan City of China. J. Food Agric. Environ. 11 (3\&4), 259-262.

Rahimi, E., 2013. Lead and cadmium concentrations in goat, cow, sheep, and buffalo milks from different regions of Iran. Food Chem. 136 (2), 389-391.

Ran, J., Wang, D., Wang, C., Zhang, G., Zhang, H., 2016. Heavy metal contents, distribution, and prediction in a regional soil-wheat system. Sci. Total Environ. 544, 422-431.

Rey-Crespo, F., Miranda, M., López-Alonso, M., 2013. Essential trace and toxic element concentrations in organic and conventional milk in NW Spain. Food Chem. Toxicol. $55,513-518$

Sarkar, P., Ray, P., Ghatak, P., Sen, M., 2016. Arsenic concentration in water, rice straw and cow milk - a micro level study at Chakdaha and Haringhata block of West Bengal. Ind. J. Dairy Sci. 6 (69), 676-679.

Shailaja, M., Reddy, Y.S., Kalakumar, B.D., Brinda, S.A., Manohar, G., Kumar, B.D., 2014. Lead and trace element levels in milk and blood of buffaloes (Bubalus bubalis) from Hyderabad, India. Bull. Environ. Contam. Toxicol. 92, 698-702.

Swarup, D., Patra, R.C., Naresh, R., Kumar, P., Shekhar, P., 2005. Blood lead levels in lactating cows reared around polluted localities; transfer of lead into milk. Sci. Total Environ. 347 (1-3), 106-110.

Tang, J., Huang, Z., Pan, X.D., 2014. Exposure assessment of heavy metals (Cd, Hg, and Pb) by the intake of local foods from Zhejiang, China. Environ. Geochem. Health 36 (4), 765-771.

Temiz, H., Soylu, A., 2012. Heavy metal concentrations in raw milk collected from different regions of Samsun, Turkey. Int. J. Dairy Technol. 65 (4), 516-522.

WHO, 2010. Exosure to Arsenic: A Major Public Health Concern. Public Health and Environment, World Health Organization, Geneva, Switzerland.

Zhou, X., Qu, X., Zhao, S., Wang, J., Li, S., Zheng, N., 2016. Analysis of 22 elements in milk, feed, and water of dairy cow, goat, and buffalo from different regions of China. Biol. Trace Elem. Res. 176 (1), 120-129. 